\title{
PATTERNS AND CONTROLS OF PRIMARY PRODUCTION IN THE PATAGONIAN STEPPE: A REMOTE SENSING APPROACH
}

\author{
Esteban G. Jobbágy, ${ }^{1}$ Osvaldo E. Sala, and José M. Paruelo \\ IFEVA, Facultad de Agronomía, Universidad de Buenos Aires, Avenida San Martín 4453 (1417) \\ Buenos Aires, Argentina
}

\begin{abstract}
We took advantage of regional gradients to study the spatial relationships between aboveground net primary production (ANPP) and climate in the Patagonian steppe of South America. We explored the same relationships through time, considering the natural variations of ANPP and climate for $11 \mathrm{yr}$. Based on NOAA/AVHRR satellite normalized difference vegetation index (NDVI) data, we evaluated the effects of climate on annual and seasonal ANPP across regional gradients of precipitation $(100-500 \mathrm{~mm} / \mathrm{yr})$ and temperature $\left(-1^{\circ}-9^{\circ} \mathrm{C}\right.$ of annual mean). We studied ANPP climatic controls through time at four sites using NDVI and meteorological data.

We used annual NDVI integral as a surrogate of annual ANPP. Annual NDVI integral increased linearly along regional gradients of precipitation, and its annual variability decreased exponentially. Annual NDVI integral was, in most cases, unrelated to precipitation through time. We described the seasonality of ANPP using four variables derived from seasonal NDVI curves: the dates of growing season start and end, the date of maximum NDVI, and the length of the growing season. The growing season started later toward the cold extreme of the regional temperature gradients and, within a given site through time, during the coldest years. The dates of maximum NDVI and end of the growing season occurred later toward the humid or cold extremes of the regional gradients, whereas the length of the growing season was positively affected by precipitation and temperature along these gradients. These variables were not associated with climate through time. The response of the start of the growing season to temperature was greater in time, following the natural climatic fluctuations, than in space, accompanying regional temperature gradients. This difference probably resulted because the time required for shifts in community composition and plant adaptation is longer than one year. Climatic determinants of ANPP shifted from precipitation alone to precipitation plus temperature when the temporal scale of analysis changed from annual to seasonal. Our results indicate the feasibility of forecasting forage availability a few months prior to the beginning of the growing season, but not during the whole year. Longer term data sets and manipulative experiments are required to forecast annual ANPP and predict its response to climate change.
\end{abstract}

Key words: aboveground net primary production (ANPP); arid ecosystems; forage production; grasslands ecology; NDVI; NOAA/AVHRR; Patagonia; rangelands; remote sensing; seasonality; steppe.

\section{INTRODUCTION}

Regional environmental gradients provide a unique opportunity to explore ideas and models about ecosystem functioning, to assess their level of generality, and to project them at the global scale (Burke et al. 1998, Burke 2000). The isolation of variables like temperature or substrate age within a regional environmental matrix has been extremely useful to understand the controls of ecosystem processes like soil formation (Jenny 1941) or nutrient cycling (Vitousek et al. 1992, 1994). In the case of carbon cycling, the study of primary production, decomposition, and soil organic matter storage across regional climatic gradients has yielded general principles about the influence of climate on

Manuscript received 23 November 1998; revised 16 July 1999; accepted 4 August 1999; Special Feature accepted 2 May 2001. For reprints of this Special Feature, see footnote 1, p. 305.

${ }^{1}$ E-mail: jobbagy@agro.uba.ar carbon dynamics (Meentemeyer 1978, Sala et al. 1988, Burke et al. 1989, as reviewed in Burke et al. 1998). Even though regional gradients provide a powerful framework for understanding the effects of climate change on the global carbon cycle, the extrapolation of spatial relationships to the temporal dimension is not always direct, as it has been shown for relationships between primary production and precipitation (Lauenroth and Sala 1992).

The direct observation of ecosystem processes at large spatial scales (e.g., remote sensing of primary production, watershed integration of nutrient outputs) across regional gradients is an effective way to gain knowledge about ecosystem functioning at the scale at which the most important global change components take place (Wessman 1992). In the particular case of semiarid grazing ecosystems, where land use decisions occur at large spatial scales, the assessment of primary production on a regional basis can assist in a more 
efficient and sustainable use of forage resources (Graetz 1991).

In this paper we explore spatial and temporal relationships between climate and aboveground net primary production (ANPP) in one of the largest semiarid regions subject to grazing: the Patagonian steppe of South America. We take advantage of broad, regional climatic gradients to evaluate a group of hypotheses about the role of temperature and precipitation in primary production in space. We evaluate the same hypotheses through time, studying the natural fluctuations of climate and primary production during $11 \mathrm{yr}$.

Biomass harvesting is the most common way to estimate ANPP in grasslands (Singh et al. 1975, Lauenroth et al. 1986), but because of the large effort and detailed spatial scale, harvest methods constrain both the temporal resolution and the spatial extent of ANPP data. Radiometric measurements are a fast and nondestructive option for ANPP assessment (Tucker 1980, Gamon et al. 1995). Satellite radiometric measurements have the advantage of large area coverage and high temporal resolution. Normalized difference vegetation index (NDVI) is the most commonly used radiometric index for estimating ANPP (Tucker and Sellers 1986, Paruelo et al. 1997). There is a direct relationship between the integral of NDVI and the absorbed photosynthetically active radiation (APAR) of plant canopies (Gallo et al. 1985, Goward et al. 1994, Law and Waring 1994). In ecosystems dominated by grasses or deciduous life-forms, APAR and net primary production are directly related (Monteith 1981). This is the basis of the commonly observed relationship between NDVI and ANPP (Tucker and Sellers 1986, Box et al. 1989, Kennedy 1989, Prince 1991, Running 1990, Paruelo et al. 1997).

ANPP increases linearly along spatial precipitation gradients within the range of 200-1300 mm/yr in North American, South American, and African grasslands (Webb et al. 1978, Lauenroth 1979, Sala et al. 1988, McNaughton et al. 1993, Paruelo et al. 1997). The picture of how ANPP varies through time is less clear. The temporal models relating time series of ANPP and annual precipitation for single sites have shown lower slopes and regression coefficients than the spatial models (Smoliak 1986, LeHouérou et al. 1988, Lauenroth and Sala 1992, Briggs and Knapp 1995).

Lauenroth and Sala (1992) suggested that the differences between the spatial and temporal models can be the result of the long- and short-term effects of climate on ANPP. The variation of precipitation along spatial gradients causes changes of ANPP, with parallel shifts in plant community structure, such as plant functional type (Chapin 1993) or floristic composition. In contrast, the fluctuation of precipitation through time, from year to year, affects ANPP without causing important changes in vegetation structure. Spatial gradients reflect long-term effects of precipitation on ANPP, whereas year-to-year fluctuations reflect short-term effects of precipitation on ANPP.

Previous primary production estimates for the $\mathrm{Pa}$ tagonian steppe showed a regional pattern associated with precipitation, but did not have a sufficient time span to assess annual variability patterns and to relate them with year-to-year environmental variation (Deffosé et al. 1990, Fernández et al. 1991, Paruelo et al. 1991, 1993). Understanding ANPP patterns and controls through time is particularly urgent in a region like the Patagonian steppe, where grazing is the most important economic activity and coping with temporal changes in the availability of forage becomes a major step toward an efficient and sustainable use of the natural vegetation (Hodgkinson 1992).

A group of hypotheses guided our analysis of the climatic controls of ANPP in the Patagonian steppe. We proposed specific hypotheses for the annual and seasonal scales, and we derived predictions to be tested.

\section{Annual primary production}

Precipitation, through its effect on water availability, is the major control of annual ANPP in the Patagonian steppe. We predicted that (1) the annual integral of NDVI, our estimate of annual ANPP, would be positively associated with annual precipitation. Because the average amount of precipitation is inversely related to the variability of precipitation (Noy Meir 1973, Ehleringer 1995, Jobbágy et al. 1995), we also expected (2) a negative relationship between the mean annual integral of NDVI and the interannual variability of the NDVI integral.

\section{Seasonality of primary production and temperature}

Temperature is the key control over ANPP in the Patagonian steppe at the beginning of the growing season when the soil is wet. We predicted a delay in the starting date of the growing season as temperature decreases.

\section{Seasonality of primary production and precipitation}

Although temperature determines the beginning of the growing season, precipitation, through its effect on water availability, controls ANPP during the rest of the growing season. Once the growing season has started, water availability decreases and constrains productivity, slowing down growth first, and then determining the end of the growing season during summer or fall. We predicted a delay in the date of maximum ANPP and the end of the growing season as precipitation increases, and an increase in the growing season length with increasing precipitation. We expected our predictions to occur both in space, along climatic gradients, and through time, following local climatic fluctuations. We tested them in the main vegetation types of the Patagonian steppe using satellite NDVI data. 


\section{Materials ANd Methods}

\section{The region}

The Patagonian steppe is a large arid and semiarid region located in the southern portion of South America. Its western sector encompasses a strong west-toeast precipitation gradient associated with the prevailing west winds that gradually lose their humidity along the Andean slopes. Precipitation ranges from $500 \mathrm{~mm} /$ $\mathrm{yr}$ on the foothills of the Andes to $100 \mathrm{~mm} / \mathrm{yr}$ in the central portion of the region (Walter and Box 1983, Jobbágy et al. 1995). More than $70 \%$ of annual precipitation is concentrated in fall and winter. Shrubs and perennial grasses are the dominant components of the steppe. Most of the shrubs are deciduous, whereas grasses have some green leaves during the entire year. The whole region is grazed by sheep, and herds are sustained only by natural vegetation (Soriano 1983). Along the west-east precipitation gradient, important vegetation changes occur, from grass steppes to grassshrubsteppes, and finally dwarf shrubsteppes (Soriano 1956).

\section{The data}

We estimated annual and seasonal ANPP dynamics from the seasonal course of the Normalized Difference Vegetation Index (NDVI) derived from AVHRR/ NOAA satellites. NDVI combines spectral data of channel 1 (red, 580-680 nm) and channel 2 (near infrared, 725-1100 nm): NDVI $=($ channel $2-$ channel 1)/(channel $2+$ channel 1) (Tucker and Sellers 1986). We used the NOAA/NASA Pathfinder AVHRR land data set, created by NASA (James and Kallury 1994). This data set comes from NOAA-7, 9, and 11 satellite imagery and was radiometrically and spatially corrected (for details, see Rao 1993, James and Kallury 1994). The scenes have a spatial resolution of $8 \times 8$ $\mathrm{km}$. We used the 10-d maximum value composite for the 1981-1991 period (Holben 1986). Radiometric measurements performed by satellites are influenced by geometric aspects such as the relative position and angle of the target, the sensor, and sunlight; and by atmospheric variables such as cloud and aerosol contamination (Ruimy et al. 1994). All of these factors tend to decrease NDVI. Maximum value composites help to filter NDVI errors by selecting the maximum NDVI reading of a pixel for a given temporal sequence of images (Holben 1986).

We obtained the geographic coordinates and elevation for each pixel from the Pathfinder ancillary data set. We also used more spatially detailed satellite data (Local Area Coverage AVHRR/NOAA data, pixel size: $1 \times 1 \mathrm{~km}$ ) for the visible, near infrared, and thermal channels to select our study areas and to discard pixels occupied by forest or with a high percentage of wetlands, water bodies, or rock outcrops. We processed the imagery with an ERDAS 7.4 system (ERDAS Incorporated, Atlanta, Georgia, USA).
We tested our hypotheses in space along two westeast transects that encompassed the entire regional precipitation gradient (north and south precipitation transects) and two elevation transects that included large temperature gradients (east and west elevation transects; Fig. 1, Table 1). We obtained mean annual precipitation values for each $8 \times 8 \mathrm{~km}$ pixel using available precipitation records and geographical interpolation models calibrated for each transect (Jobbágy et al. 1995). We looked for smooth elevation gradients to allow for a proper description of the altitudinal changes with coarse-resolution satellite data. Another requirement of the elevation gradients was their north-south orientation, orthogonal to the main regional precipitation gradient. We selected two north-south elevation transects on the Lake Buenos Aires plateau with elevation ranges of $1350 \mathrm{~m}$ and $1000 \mathrm{~m}$, encompassing together more than $9^{\circ} \mathrm{C}$ of mean annual temperature change (east and west elevation transects, Fig. 1, Table 1). We calculated temperature values for each $8 \times 8$ $\mathrm{km}$ pixel along the two elevation gradients, considering a mean annual temperature lapse rate of $0.7^{\circ} \mathrm{C}$ for every $100 \mathrm{~m}$ of elevation increase (Baker 1944, Barry 1981).

We tested our hypotheses through time, considering year-to-year climatic variation at four steppe sites. We chose sites in Argentina and Chile that had reliable daily precipitation and temperature data during the same period for which satellite data were available (Fig. 1, Table 1). These sites were Rio Mayo experimental station (Argentina), Balmaceda (Chile), Perito Moreno (Argentina), and Esquel airport (Argentina). We selected areas of $2 \times 2$ pixels $\left(256 \mathrm{~km}^{2}\right)$ on a representative pure rangeland area within a $15-\mathrm{km}$ distance from their corresponding meteorological station.

\section{The analysis of annual primary production}

We calculated the NDVI integral from spring to fall, for the period between 1 September and 30 April of each year. We excluded winter months because of missing data during this season in some years. To evaluate our prediction that annual ANPP is controlled by precipitation in space, we analyzed the variation of the 11-yr average NDVI integral along the precipitation and elevation transects. To evaluate the same predictions through time, we explored the statistical relationship of the annual NDVI integral with precipitation and temperature at the four sites. To evaluate possible lags in ANPP responses to precipitation, we computed two annual precipitation values: one for the July-June period and other for the January-December period. We also considered seasonal precipitation sums as independent variables in our analyses (all possible periods of six and three months). We explored the relationship between the temporal variability of annual NDVI integral among years, calculated as the interannual coefficient of variation (CV), and the mean annual NDVI integral along the west-east precipitation gradients. 

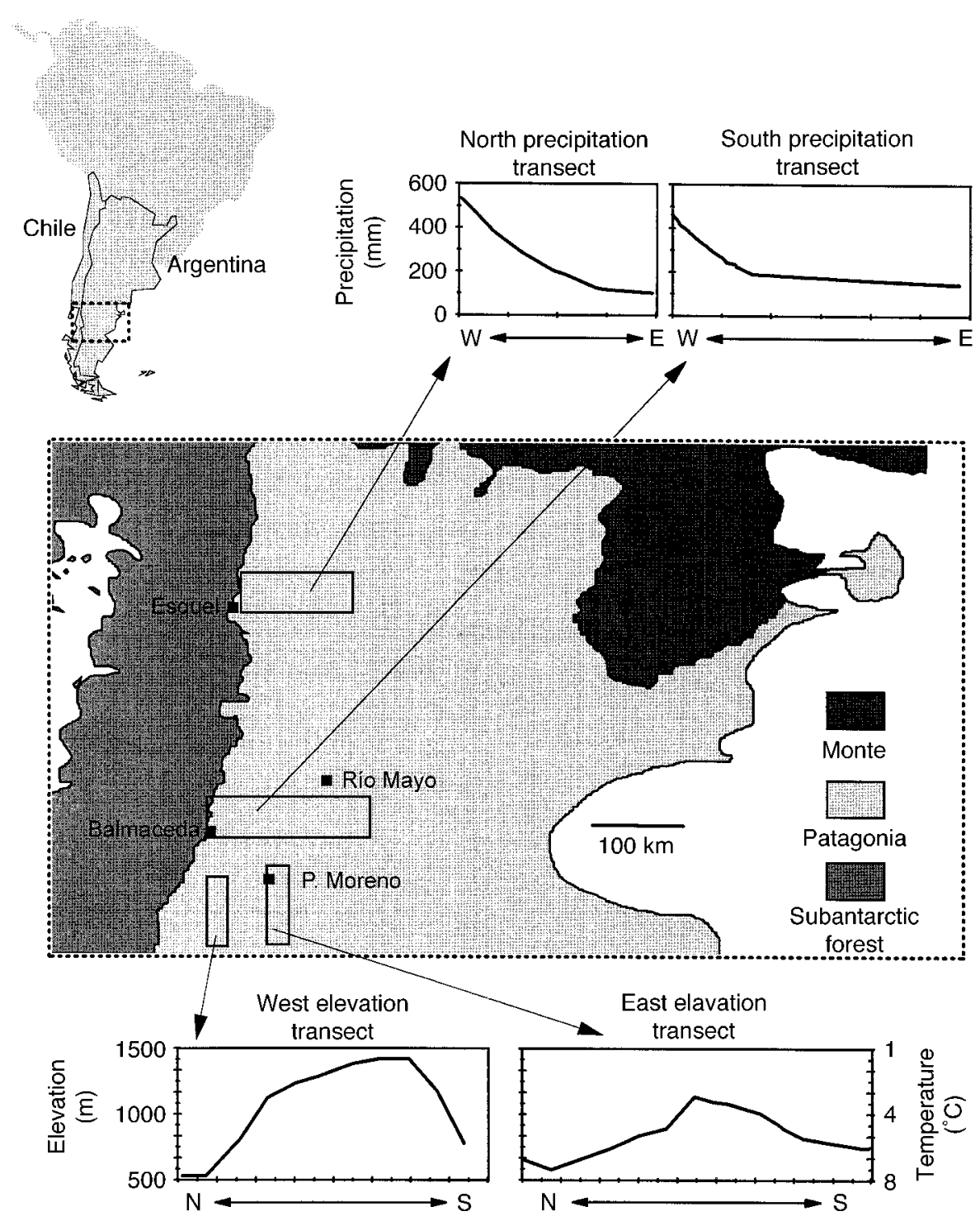

FIG. 1. The upper map shows the location of the study region in South America. The lower map displays the areas occupied by Patagonian steppe, adjacent Monte shrubland, and subantarctic forest (Soriano 1956). Rectangles indicate the location of transects used for spatial analysis of the relationship between climate and primary production. Black squares show the locations of the four sites used for temporal analyses. Near each square $(<15 \mathrm{~km})$ there is a meteorological station with available precipitation and temperature data for the study period.

\section{The analysis of primary production seasonality}

We obtained seasonal curves of NDVI for every single pixel and for each of the $11 \mathrm{yr}$ of our data set. We derived four variables from these curves: the date of maximum NDVI, the starting date of the growing season, the ending date of the growing season, and the growing season length. The starting and ending dates of the growing season were considered as the day of the year when the NDVI curve intercepted an NDVI threshold that was one-fourth of the difference between the pixel average NDVI maximum and average NDVI minimum. This NDVI threshold was independently calculated for each pixel, making our criteria for growing season start and end dependent on the productivity of the pixel. The threshold of one-fourth represented the lowest value that ensured an actual detection of the growing season start without detecting just a small, isolated NDVI peak or imagery noise during winter months. The length of the growing season was the number of days between the growing season start and end.

To evaluate the predictions about primary production seasonality in space, we calculated the 11-yr average of the four seasonal NDVI variables for every single pixel. We explored the changes of these variables along the regional precipitation and elevation transects. To evaluate the predictions about primary production sea- 
TABLE 1. Transects used for the spatial analysis and sites used for the temporal analysis, together with their physical features, annual rainfall, and vegetation physiognomic types.

\begin{tabular}{|c|c|c|c|c|c|c|c|}
\hline \multirow{2}{*}{$\begin{array}{l}\text { Transect } \\
\text { and site } \dagger\end{array}$} & \multicolumn{2}{|c|}{ Latitude, longitude $\neq$} & \multirow{2}{*}{$\begin{array}{c}\text { Area } \\
\left(\mathrm{km}^{2}\right)\end{array}$} & \multirow{2}{*}{$\begin{array}{l}\text { Elevation } \\
\text { (m) }\end{array}$} & \multirow{2}{*}{$\begin{array}{l}\text { Precipitation } \\
\quad(\mathrm{mm} / \mathrm{yr})\end{array}$} & \multirow{2}{*}{$\begin{array}{l}\text { Vegetation } \\
\text { type }\end{array}$} & \multirow[b]{2}{*}{ Reference } \\
\hline & Upper-left & Lower-right & & & & & \\
\hline \multicolumn{8}{|l|}{ Precipitation§ } \\
\hline North & $-42.5,-71.3$ & $-43.0,-70.0$ & 5000 & $600-1000$ & $100-500$ & $\begin{array}{l}\text { semidesert/ } \\
\text { grass steppe } \\
\text { continuum }\end{array}$ & $\begin{array}{l}\text { Jobbágy et al. } \\
\text { (1996) }\end{array}$ \\
\hline South & $-45.5,-71.7$ & $-46.0,-69.8$ & 7000 & $450-950$ & $140-500$ & $\begin{array}{l}\text { semidesert/ } \\
\text { grass steppe } \\
\text { continuum }\end{array}$ & $\begin{array}{l}\text { León and Fa- } \\
\text { celli (1981) }\end{array}$ \\
\hline \multicolumn{8}{|l|}{ Elevation } \\
\hline West & $-46.4,-71.5$ & $-47.0,-71.7$ & 1500 & $250-1600$ & 180 & $\begin{array}{l}\text { grass-shrub- } \\
\text { steppe/grass } \\
\text { steppe }\end{array}$ & $\begin{array}{l}\text { M. Nogués, } \\
\text { unpublished } \\
\text { data }\end{array}$ \\
\hline East & $-46.4,-71.0$ & $-47.0,-70.8$ & 1500 & $300-1300$ & 120 & $\begin{array}{l}\text { semidesert/ } \\
\text { grass- } \\
\text { shrubsteppe }\end{array}$ & $\begin{array}{l}\text { M. Nogués, } \\
\text { unpublished } \\
\text { data }\end{array}$ \\
\hline RM & $-45.3,-70.4$ & $-45.4,-70.3$ & 250 & 500 & 150 & $\begin{array}{l}\text { grass-shrub- } \\
\text { steppe }\end{array}$ & $\begin{array}{l}\text { Golluscio et } \\
\text { al. (1982) }\end{array}$ \\
\hline BM & $-45.9,-71.7$ & $-46.0,-71.6$ & 250 & 620 & 500 & grass steppe & $\begin{array}{l}\text { León and Fa- } \\
\text { celli (1981) }\end{array}$ \\
\hline ES & $-42.9,-71.4$ & $-43.0,-71.5$ & 250 & 780 & 450 & grass steppe & $\begin{array}{l}\text { Jobbágy et al. } \\
\text { (1996) }\end{array}$ \\
\hline PM & $-46.5,-71.0$ & $-46.6,-70.9$ & 250 & 430 & 120 & $\begin{array}{l}\text { grass-shrub- } \\
\text { steppe/semi- } \\
\text { desert }\end{array}$ & $\begin{array}{l}\text { M. Nogués, } \\
\text { unpublished } \\
\text { data }\end{array}$ \\
\hline
\end{tabular}

$\dagger$ Abbreviations are as follows: RM, Río Mayo; BM, Balmaceda; ES, Esquel; and PM, Perito Moreno.

\$ Latitude (degrees South) and longitude (degrees West) of the upper-left and lower-right corners of the transects and sites.

$\S$ Precipitation transects encompass a continuum of physiognomies, total cover, and percentage shrubs.

sonality in time, we analyzed the relationship between year-to-year variation of the seasonal NDVI variables and temperature and precipitation fluctuations in the four local sites (Fig. 1, Table 1). We evaluated several variables derived from temperature and precipitation that included monthly and seasonal averages (all possible six and three adjacent month periods) and, in the case of temperature, also degree-days sums using base temperatures of $0^{\circ}, 5^{\circ}$, and $10^{\circ} \mathrm{C}$.

\section{RESULTS}

\section{Annual primary production}

Annual NDVI integral was linearly and positively associated with mean annual precipitation along regional west-east gradients (Fig. 2a). The slopes of the NDVI integral-mean annual precipitation relationship differed significantly between the two precipitation transects.

The natural fluctuations among years of NDVI integral and annual precipitation, during the 11-yr period of study, were significantly related only in the grass steppe site of Balmaceda (NDVI integral $=0.0578+$ 0.00011 annual precipitation; $R^{2}=0.55 ; P<0.05$; annual precipitation was computed for the JanuaryDecember period). In the other sites, we did not find any significant relationship $(P<0.05)$ between NDVI integral and climatic variables through time.

Along the temperature gradient, annual NDVI integral displayed an optimum function with its maximum at $4^{\circ}$ and $5.5^{\circ} \mathrm{C}$ for the west and east elevation transects, respectively (Fig. 2b). The temporal variability of annual NDVI integral, measured by its interannual $\mathrm{CV}$, declined exponentially along the mean NDVI integral and precipitation gradients. At the most arid end of the transect, the $\mathrm{CV}$ was $>80 \%$, whereas at the humid extreme, the $\mathrm{CV}$ tended to reach a plateau at $10 \%$ (Fig. 2c).

Our regression analyses indicated that precipitation largely accounted for average annual ANPP across regional spatial gradients, explaining $79-95 \%$ of the variance, but was a weak explanatory variable through time, because only one out of four sites had a statistically significant NDVI integral-precipitation relationship. As predicted, the temporal variability of annual NDVI decreased rapidly as mean annual NDVI increased (Fig. 2c).

\section{Seasonality of primary production and temperature}

Our results supported the hypothesis that temperature controls the start of the growing season in space and time. The start of the growing season was linearly and negatively associated with mean annual temperature along regional temperature gradients, i.e., cooler sites started their growing season later (Fig. 3a). The growing season began in late September at warmer, low-elevation sites and in mid-November at cooler, high-elevation sectors. The fitted functions were essentially the same for the two elevation transects (no significant differences of slope and intercept), and the average decrease was $4 \mathrm{~d}$ for every degree Celsius of 

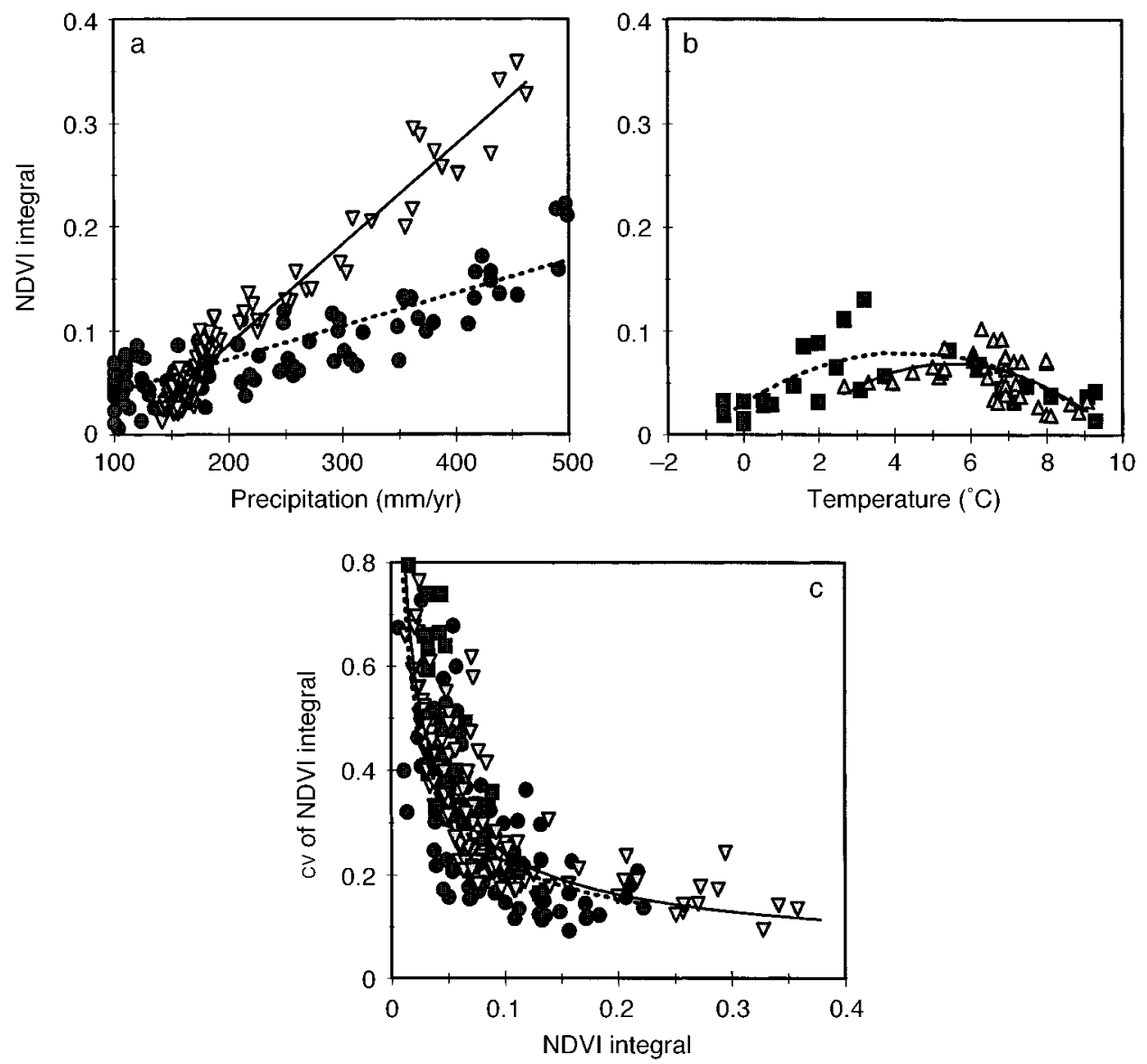

FIG. 2. Annual aboveground net primary production (ANPP) in the Patagonian steppe estimated by the annual NDVI integral (satellite normalized difference vegetation index) along precipitation and temperature gradients, and the relationship between mean annual ANPP and interannual variability. Data and regression models, respectively, are indicated as follows: circles and dashed lines for the north precipitation transect; inverted triangles and solid lines for the south precipitation transect; squares and dashed lines for the west elevation transect; and triangles and solid lines for the east elevation transect. The average NDVI integral is shown (a) as a function of mean annual precipitation in the north and south transects, and (b) as a function of mean annual temperature in the east and west transects. (c) The interannual coefficient of variation (CV) of the NDVI integral is shown as a function of the mean NDVI integral for the north and south transects. Each data point represents the average value for the 1981-1991 period for a single $8 \times 8 \mathrm{~km}$ pixel. See Table 2 for regression model calculations and their statistical significance.

TABLE 2. Models and their statistical significance for the four study transects, showing regressions of NDVI integral (estimated ANPP, aboveground net primary production) vs. precipitation (north and south transects; Fig. 2a) and vs. temperature (east and west transects; Fig. 2b).

\begin{tabular}{|c|c|c|c|c|}
\hline $\begin{array}{l}\text { Measurement, } \\
\text { by transect }\end{array}$ & Reference & Formula & $R^{2}$ & $P$ \\
\hline \multicolumn{5}{|c|}{ Average NDVI integral } \\
\hline $\begin{array}{l}\text { N. precipitation } \\
\text { S. precipitation } \\
\text { W. elevation } \\
\text { E. elevation }\end{array}$ & $\begin{array}{l}\text { Fig. 2a } \\
\text { Fig. 2a } \\
\text { Fig. 2b } \\
\text { Fig. 2b }\end{array}$ & $\begin{array}{l}0.0066+0.0003 \text { precipitation } \\
-0.1056+0.0010 \text { precipitation } \\
-0.00263\left(\text { mean annual } \mathrm{T}^{\circ}\right)^{2}+0.0230 \text { mean annual } \mathrm{T}^{\circ}+0.0301 \\
-0.00361\left(\text { mean annual } \mathrm{T}^{\circ}\right)^{2}+0.0398 \text { mean annual } \mathrm{T}^{\circ}-0.0406\end{array}$ & $\begin{array}{l}0.79 \\
0.95 \\
0.51 \\
0.30\end{array}$ & $\begin{array}{l}<0.0001 \\
<0.0001 \\
<0.0001 \\
<0.0001\end{array}$ \\
\hline \multicolumn{5}{|c|}{$\log \mathrm{CV}$ of NDVI integral } \\
\hline $\begin{array}{l}\text { N. precipitation } \\
\text { S. precipitation }\end{array}$ & $\begin{array}{l}\text { Fig. 2c } \\
\text { Fig. 2c }\end{array}$ & $\begin{array}{l}-1.20-0.54 \log \text { NDVI integral } \\
-1.19-0.56 \log \text { NDVI integral }\end{array}$ & $\begin{array}{l}0.49 \\
0.83\end{array}$ & $\begin{array}{l}<0.0001 \\
<0.0001\end{array}$ \\
\hline
\end{tabular}

Note: Precipitation is measured in $\mathrm{mm} / \mathrm{yr}$ and temperature $\left(\mathrm{T}^{\circ}\right)$ is measured in degrees Celsius. Interannual variability in ANPP is depicted in Fig. $2 \mathrm{c}$ as the coefficient of variation of the NDVI integral as a function of the mean NDVI integral. 

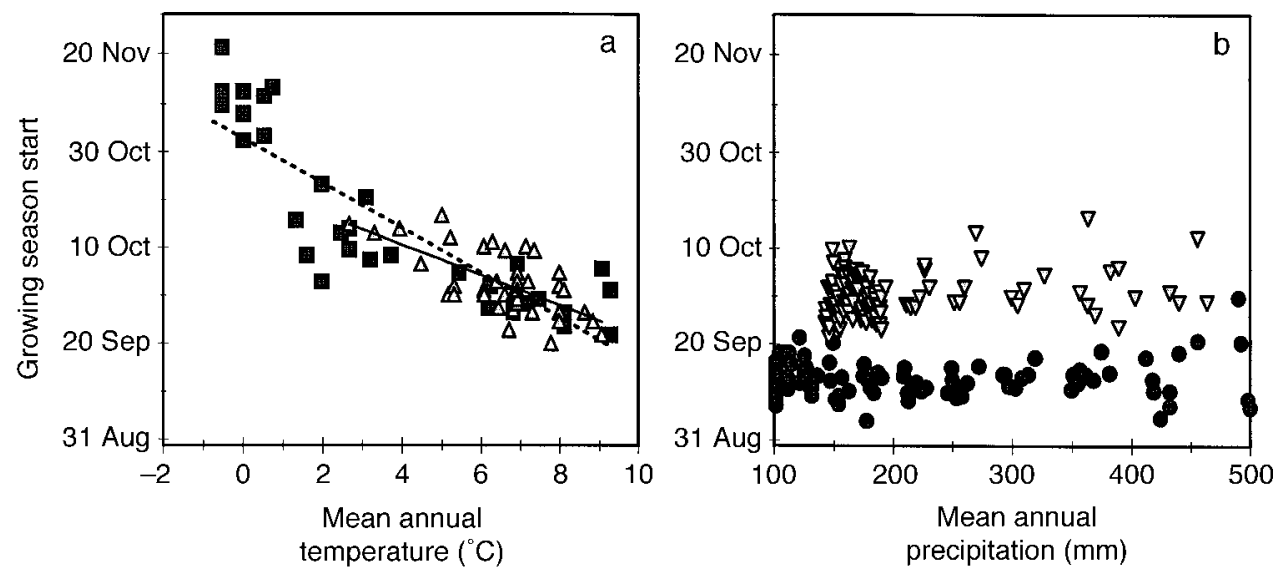

FIG. 3. Spatial variation in the date of growing season start in the Patagonian steppe. (a) Average date of growing season start as a function of mean annual temperature along the west (squares) and east (triangles) elevation transects. The regression for the west elevation transect (dashed line) is as follows: date of start (Julian date, day $1=1$ January) $=304-4.6($ mean annual temperature $\left.\left[{ }^{\circ} \mathrm{C}\right]\right) ; R^{2}=0.74, P<0.0001$. The regression for the east elevation transect (solid line) is: date of start (Julian date $=294-3.2\left(\right.$ mean annual temperature $\left.\left[{ }^{\circ} \mathrm{C}\right]\right) ; R^{2}=0.44, P<0.0001$. Mean annual temperature values were estimated from the elevation of each pixel, considering a lapse rate of $-0.7^{\circ} \mathrm{C} / 100 \mathrm{~m}$. (b) Average date of growing season start as a function of mean annual precipitation along the north (circles) and south (triangles) precipitation transects. The average starting date is $14 \mathrm{~d}$ earlier for the north than for the south transect $(P<0.0001)$. Each data point represents the average value for 1981-1991 for a single $8 \times 8 \mathrm{~km}$ pixel.

mean annual temperature. The start of the growing season was independent of mean annual precipitation and NDVI integral along the precipitation transects (Fig. $3 b)$. The growing season started in mid-September in the north precipitation transect, $14 \mathrm{~d}$ earlier than in the south precipitation transect, which had lower temperatures.

The analysis through time, comparing years in the same location instead of locations along transects, showed similar results. The start of the growing season was negatively associated with temperature, when sites were considered either separately or pooled (Fig. 4). The best explanatory variable among monthly, seasonal, and degree-days summed temperature was the mean temperature for the month of July. Mean July temperature fluctuated at least $6^{\circ} \mathrm{C}$ in each site. When mean July temperature was $<0^{\circ} \mathrm{C}$, the growing season started during October. When it was $>0^{\circ} \mathrm{C}$, the start of the

TABLE 3. Models and their statistical significance for the four study transects, showing regressions of three temporal measurements (dates of maximum NDVI, end of the growing season, and length of the growing season) vs. precipitation (north and south transects; Fig. 5a, c, and e) and vs. temperature (east and west transects; Fig. 5b, d, and f).

\begin{tabular}{|c|c|c|c|c|}
\hline Transect & Reference & Formula & $R^{2}$ & $P$ \\
\hline \multicolumn{5}{|c|}{ Date of maximum NDVI $\dagger$} \\
\hline $\begin{array}{l}\text { N. precipitation } \\
\text { S. precipitation } \\
\text { W. elevation } \\
\text { E. elevation }\end{array}$ & $\begin{array}{l}\text { Fig. 5a } \\
\text { Fig. 5a } \\
\text { Fig. 5b } \\
\text { Fig. } 5 b\end{array}$ & $\begin{array}{l}335+0.0371(\text { mean annual precipitation }) \\
340+0.0856(\text { mean annual precipitation) } \\
9-1.9\left(\text { mean annual temperature }\left[{ }^{\circ} \mathrm{C}\right]\right)\end{array}$ & $\begin{array}{l}0.41 \\
0.51 \\
0.71\end{array}$ & $\begin{array}{l}<0.0001 \\
<0.0001 \\
<0.0001 \\
\quad \text { NS }\end{array}$ \\
\hline \multicolumn{5}{|c|}{ Date of growing season end $\dagger$} \\
\hline N. precipitation & Fig. 5c & $\begin{array}{l}15.07(1-\exp [-0.00251(\text { mean annual precipitation })])+ \\
119.7\end{array}$ & 0.49 & $<0.0001$ \\
\hline $\begin{array}{l}\text { S. precipitation } \\
\text { W. elevation } \\
\text { E. elevation }\end{array}$ & $\begin{array}{l}\text { Fig. } 5 \mathrm{c} \\
\text { Fig. } 5 \mathrm{~d} \\
\text { Fig. } 5 \mathrm{~d}\end{array}$ & $\begin{array}{l}239(1-\exp [-0.00232(\text { mean annual precipitation })])+113.7 \\
142-3.1\left(\text { mean annual temperature }\left[{ }^{\circ} \mathrm{C}\right]\right)\end{array}$ & 0.38 & $\begin{array}{l}<0.0001 \\
\text { NS } \\
<0.0001\end{array}$ \\
\hline \multicolumn{5}{|c|}{ Length of growing season (d) } \\
\hline N. precipitation & Fig. 5e & $\begin{array}{l}14.75(1-\exp [-0.00793(\text { mean annual precipitation })])+ \\
226.6\end{array}$ & 0.23 & $<0.001$ \\
\hline S. precipitation & Fig. 5e & $\begin{array}{l}234.7(1-\exp [-0.022(\text { mean annual precipitation })])-11.71 \\
31.1\left(1-\exp \left[-0.672\left(\text { mean annual temperature }\left[{ }^{\circ} \mathrm{C}\right]\right)\right]\right)+\end{array}$ & 0.19 & $<0.001$ \\
\hline $\begin{array}{l}\text { W. elevation } \\
\text { E. elevation }\end{array}$ & $\begin{array}{l}\text { Fig. } 5 f \\
\text { Fig. } 5 f\end{array}$ & 180.7 & 0.66 & $\begin{array}{l}<0.0001 \\
\text { NS }\end{array}$ \\
\hline
\end{tabular}

Note: Precipitation is measured in $\mathrm{mm} / \mathrm{yr}$, and temperature is measured in degrees Celsius.

$\dagger$ Julian date, day $1=1$ January. 


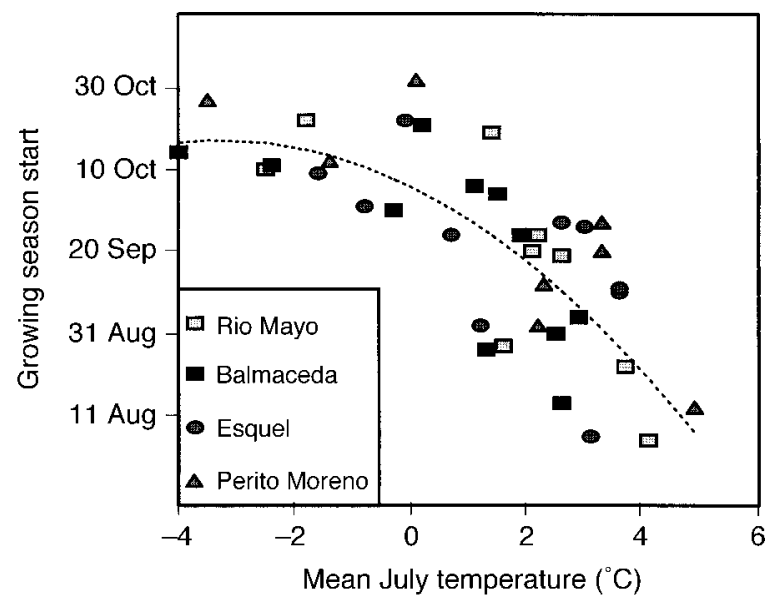

FIG. 4. Temporal variation in the date of growing season start in the Patagonian steppe. The growing season start was estimated every year from NDVI seasonal curves for four sites during 1981-1991. The best fit with climatic variables was obtained with July mean temperature $\left(\mathrm{T}^{\circ}\right)$ and a quadratic model. The regression model for all the sites pooled is: date of start $($ Julian $)=-1.1\left(\text { July T }^{\circ}\right)^{2}-7.1\left(\right.$ July T $\left.^{\circ}\right)+278 ; R^{2}$ $=0.57, P<0.001$. Each data point represents the spatial average of four pixels for a single year.

growing season was earlier, with mid-August being the earliest date for all sites. This relationship, which showed a delay in the start of the growing season as temperature decreased, and a threshold of no further change below $\sim 0^{\circ} \mathrm{C}$, was described by a quadratic model (Fig. 4). Precipitation was not significantly associated with the start of the growing season through time.

\section{Seasonality of primary production and precipitation}

The date of maximum NDVI was positively associated with mean annual precipitation along both rainfall transects (Fig. 5a). For every $100 \mathrm{~mm}$ of rainfall increase, maximum NDVI occurred 3 and $8 \mathrm{~d}$ later in the north and south precipitation transect, respectively. The date of maximum NDVI occurred $2 \mathrm{~d}$ earlier for each degree Celsius of temperature increment along the west elevation transect (Fig. 5b). There was not a significant trend of spatial variation in the east elevation transect.

The growing season ended later toward the humid end of precipitation transects (Fig. 5c). Arid and less productive areas ended the growing season in late April, whereas humid and more productive sites ended between early and mid-May. At annual precipitation $>250 \mathrm{~mm}$, the ending date of the growing season achieved a plateau in the north precipitation transect. The best fit in both precipitation transects was achieved with exponential saturation response models.

The end of the growing season was negatively and linearly associated with temperature along the east elevation transect (Fig. 5d). The end of the growing season in the west elevation transect was anticipated $\sim 3$ $\mathrm{d}$ earlier per degree Celsius of mean annual temperature increase, following a parallel change with the growing season start. The date of growing season end reached its latest value at $3^{\circ} \mathrm{C}$ of mean annual temperature (this is the lowest value, however, of the elevation transects data set).

The length of the growing season (number of days elapsed from start to end of the growing season) was positively associated with precipitation in the most arid portion of precipitation transects (Fig. 5e). A saturation model showed the best fit in both precipitation transects. The growing season length achieved a plateau at $249 \mathrm{~d}$ in the north precipitation transect and $227 \mathrm{~d}$ in the south precipitation transect. Growing season length was positively related to temperature along the west elevation transect and also had a saturation response (Fig. 5f). Along this transect, growing season length increased from $168 \mathrm{~d}$ at the coldest end to $218 \mathrm{~d}$ at the warmest end, where it achieved a plateau. The east elevation transect fell within the temperature range of growing season length saturation.

Date of maximum NDVI, ending date of the growing season, and growing season length showed no significant associations with precipitation and temperature through time, when we considered the natural fluctuations of an 11-yr period at the four studied locations. We hypothesized that the date of maximum NDVI, the ending date of the growing season, and the growing season length were controlled by water availability. Our results along spatial gradients agreed with this hypothesis, but show that temperature is also a control of these seasonal characteristics of productivity.

\section{Discussion}

\section{Annual primary production}

Our spatial results support the hypothesis that there is a positive relationship between annual precipitation and aboveground net primary production (ANPP). Annual ANPP increased with precipitation in space, along regional gradients of precipitation. The linear relationship between average ANPP and precipitation confirms reported regional trends for grasslands (Sala et al. 1988). We found a difference between the two studied precipitation gradients. One possible cause of this difference is the contrasting topography of the transects (Jobbágy et al. 1996). The northern transect is located in a mountain area and showed a lower ANPP/precipitation ratio than the southern transect, which is located in a flat area. Steeper slopes in the mountain terrain could result in a higher water runoff and a lower precipitation use efficiency (Le Houérou 1984).

The relationship between annual ANPP and precipitation, observed at individual sites through time, was weak. Only one of the four studied sites showed a significant association between the two variables. Both statistical and ecological factors can determine a weak association between precipitation and ANPP through time. The span of our data set (11 years) is a possible 

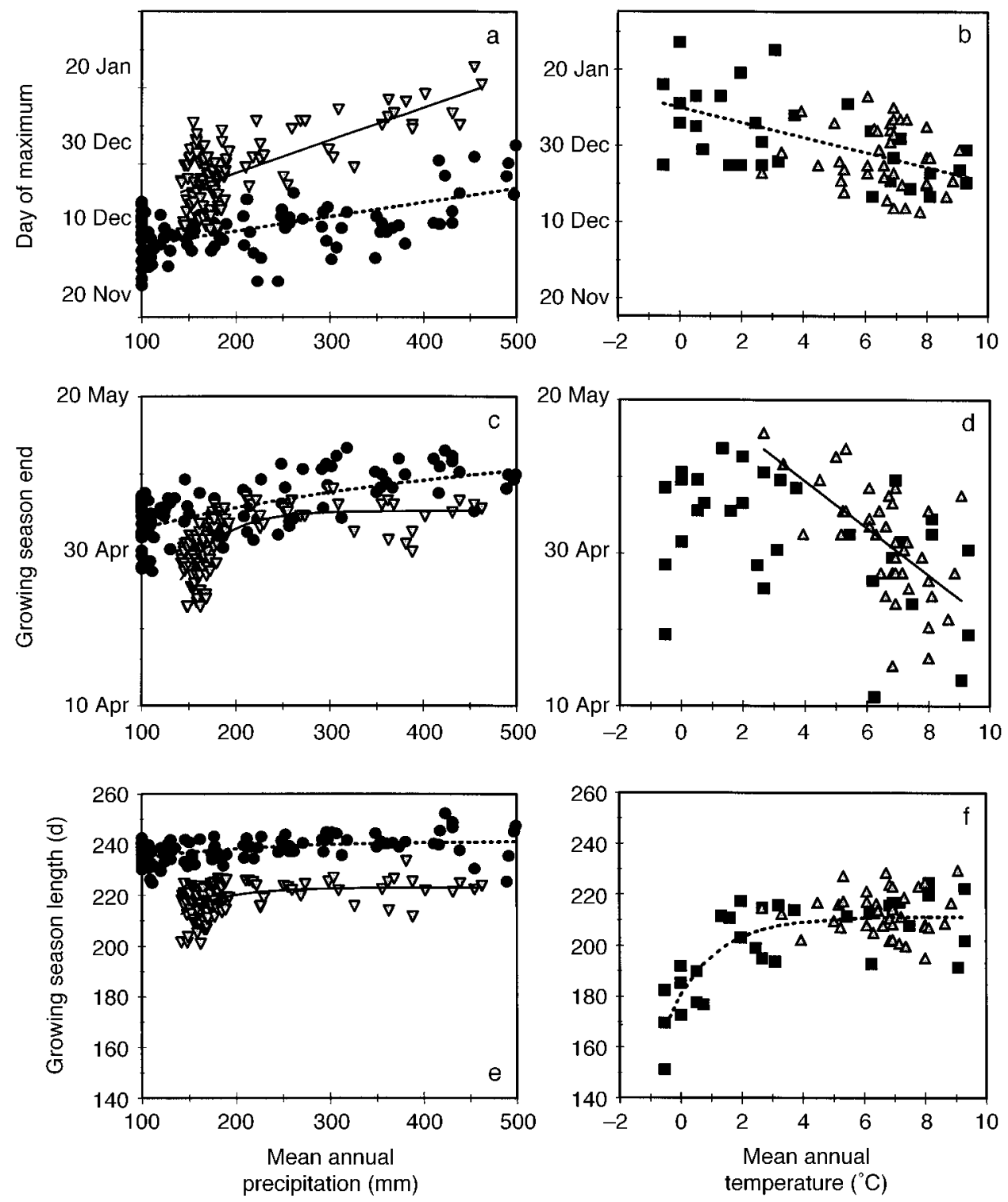

FIG. 5. Spatial changes in the date of maximum ANPP, the date of the end of the growing season, and the length of the growing season in the Patagonian steppe. The top two panels show average date (Julian, day $1=1$ January) of maximum NDVI (a) as a function of mean annual precipitation along the north (circles and dashed line regression) and south (triangles and solid line) precipitation transects and (b) as a function of mean annual temperature along the west (squares and dashed regression line) and east (triangles; regression not significant) elevation transects. The middle panels show average date of the growing season end (c) as a function of mean annual precipitation along north and south precipitation transects, with adjusted regressions corresponding to a saturation model, and (d) as a function of mean annual temperature along the west (regression not significant) and east elevation transects. The bottom panels show average growing season length, with adjusted regressions following a saturation model, (e) as a function of mean annual precipitation along the north and south transects and (f) as a function of mean annual temperature along the west and east (regression not significant) transects. Each data point represents the average value for the 1981-1991 period for a single $8 \times 8 \mathrm{~km}$ pixel. See Table 3 for regression model calculations and their statistical significance.

statistical cause of this result. We evaluated the effect of reducing the time span on a previously reported straight-line model for the relationship between precipitation and ANPP through time in the shortgrass steppe of North America (Lauenroth and Sala 1992). When the original data set of 50 years was reduced to segments of 11 years, the average level of significance of the new models dropped from $P<0.0001$ to $P=$ 0.09 and $>30 \%$ of these models were below a significance level of $P<0.05$. This reanalysis suggested that 11 years of data may not be sufficient to detect a significant relationship between precipitation and produc- 
tivity in the Patagonian steppe. Besides the statistical limitation, precipitation and ANPP may have a low association through time because of structural inertia or carryover effects (see Smoliak 1986 and Lauenroth and Sala 1992), nonlinear responses, or interactions with other resources such as nutrients (Briggs and Knapp 1995).

Annual ANPP displayed an optimum response to temperature along the elevation gradients. The observed pattern could result from the overlap of two effects of temperature on ANPP: a positive effect on the length of the growing season and a negative effect on water availability through temperature effects on atmospheric water demand. Starting from the coolest end of the temperature gradients and moving toward the warmest, the increase in temperature leads to the extension of the growing season as well as an increase of potential evapotranspiration. Because temperature is the main constraint at the cool end of the transects, its increase leads to an ANPP enhancement. There is a temperature value at which the growing season length achieves its maximum and becomes limited by water availability. Above this temperature threshold, the dominating effect of temperature is to increase atmospheric water demand and to curtail ANPP (Epstein et al. 1997).

Our analysis supported a decrease in the temporal variability in annual ANPP with increases of precipitation and ANPP. The negative association between the temporal variability and the amount of annual ANPP parallels the relationship between the temporal variability and the amount of precipitation (Noy Meir 1973, Ehleringer 1995; in Patagonia, Jobbágy et al. 1995) and the temporal variability and amount of actual evapotranspiration (Frank and Inouye 1994).

\section{Seasonality of primary production and temperature}

Our results confirmed the hypothesis that, in the $\mathrm{Pa}-$ tagonian steppe, temperature affects the starting date of the growing season. The starting date was affected by temperature in space, along the elevation transects, and through time, among years within each independent site. There were interesting differences between the spatial and temporal models derived from our data (Fig. 6). A given temperature change in space yielded a smaller response of starting date than the same change in time for a single site (Perito Moreno). The slopes for the linear models were $-3.2 \mathrm{~d} /{ }^{\circ} \mathrm{C}$ in space and -8.1 $\mathrm{d} /{ }^{\circ} \mathrm{C}$ through time; these slope differences can be explained by plant adaptations to temperature. Temperature changes in space are associated with changes in community composition, and temperature thresholds for plant growth may vary along these gradients. Plants from cold environments are adapted to grow at lower temperature than those from warmer environments. This shift in temperature response is observed for plants living under very different climates (Woodward 1987), but also for a single plant genus within a region,

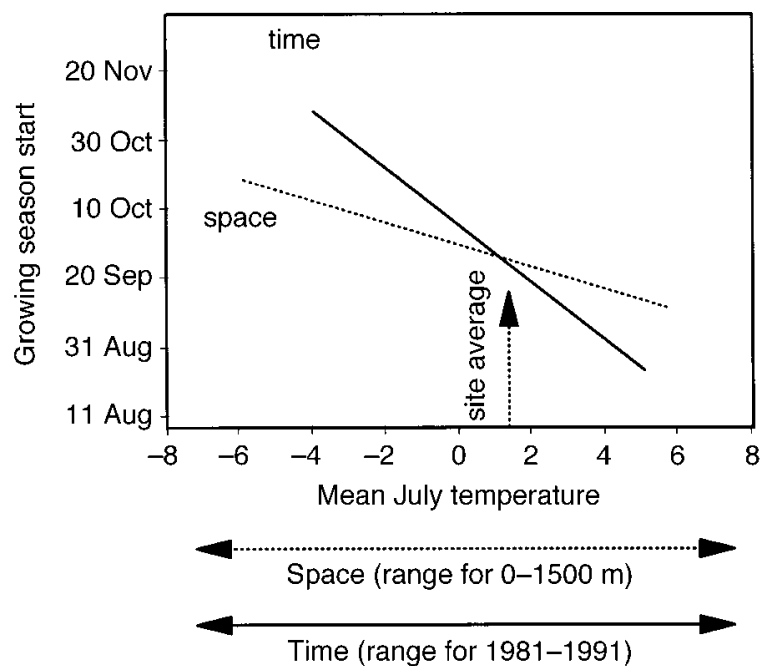

FIG. 6. Comparison of time and space models for the relationship between the day of start of the growing season and temperature $\left(\mathrm{T}^{\circ}\right)$. In the case of time, we considered a linear regression model for the Perito Moreno site. In the case of space, we used the model adjusted for the west elevation transect (see Fig. 3a). July mean temperature was used as the independent variable in the models. Perito Moreno has a longterm mean July temperature of $1.6^{\circ} \mathrm{C}$, and it is adjacent to the west elevation transect. The regression for time is: date of start $($ Julian $)=278-8.1\left(\right.$ July $\left.\mathrm{T}^{\circ}\right)$. The regression for the space model is: date of start $($ Julian $)=273-3.2\left(\right.$ July $\left.^{\circ}\right)$.

along elevation gradients (Woodward and Körner 1987). In the high Andean desert of Chile, Squeo et al. (1996) found a $6^{\circ} \mathrm{C}$ decrease of injury temperature of plants per 500-m elevation increase. Our results in the spatial dimension may include an underlying shift in the temperature thresholds of plant communities that may not be able to occur through time. The temporal analysis is based on observations of the same community subjected to natural temperature fluctuations. In this case, there are no possibilities of shifts in temperature thresholds; the community has a limited compensation and thus a higher response to temperature change.

The difference between spatial and temporal models for temperature is the opposite of a relationship reported between spatial and temporal models for the ANPP-precipitation relationship (Lauenroth and Sala 1992). However, both can be explained by time lags in vegetation to adjust to changes in either water availability or temperature. Spatial models describe the variation of populations, communities, and ecosystems in equilibrium with their environment. Temporal models describe year-to-year responses that integrate current and past conditions. The difference between spatial and temporal models represents the magnitude of the limitation of ecosystem response to interannual variability. These limitations can result from lags and constraints in the ability of individuals to acclimate, populations to adapt, and communities to shift. The closer the tem- 
poral ANPP-climate relationship is to its spatial counterpart, the greater the ability of the system to track year-to-year variability and, consequently, the higher the water utilization and water use efficiency.

In the Patagonian cold steppe, adaptations for growth at low temperatures result in an early start of the growing season and represent an adaptive advantage, because rainfall is concentrated in winter. Water can be either evaporated from the soil or absorbed and transpired by plants; only the second pathway is directly associated with production. The earlier plants start to be active, the greater will be the fraction of total water following the transpiration pathway and total production. For example, a site with an average July temperature of $2^{\circ} \mathrm{C}$ during an unusually cold year, with a July temperature of $-4^{\circ} \mathrm{C}$, may start the growing season in the middle of November. In contrast, a site with an average July temperature of $-4^{\circ} \mathrm{C}$ under similar conditions will start the growing season much earlier, possibly at the beginning of October. A lower fraction of available water will be lost via soil evaporation during spring at the later site. The closer the temporal model of the relationship between growing season start and temperature is to the same model in space, the faster are the adaptations of populations or shifts in community composition and, consequently, the greater are water use efficiency and production.

Among years, winter temperature was a better explanatory variable of the growing season start (usually occurring during spring) than was spring temperature. There may be biological and climatic explanations for the relationship between winter temperature, and not spring temperature, and the beginning of the growing season. The biological explanation may be that winter temperature affects the initial bud and tiller formation, which will constrain growth during spring. The climatic explanation could be a positive association between temperature deviations from the mean during consecutive months. We found this type of association between winter and spring months in all of the study sites.

\section{Seasonality of primary production and precipitation}

Our results partially supported the hypothesis that the date of maximum NDVI, the growing season end, and the length of the growing season were controlled by water availability. The start of the growing season did not vary along precipitation gradients. However, the peak of maximum productivity and the end of the growing season were achieved later in the more productive grass steppes at the humid end of the precipitation gradients; this resulted in an increase in growing season length. Both growing season end and length reached a plateau at intermediate precipitation levels, indicating a possible shift from a precipitation to a temperature constraint.

To explore the effect of temperature independently of the effect of precipitation, our elevation transects were orthogonal to the main west-east precipitation gradient of the region. Precipitation may increase slightly with elevation along our transects, as it typically does in other temperate mountain regions of the world (Barry 1981). Our results revealed an overwhelming effect of temperature on the starting date and length of the growing season. Along an elevation gradient dominated by the effects of precipitation, we should expect a constant starting date and an increase in the length of the growing season with elevation. Our results did not support these predictions. The starting date of the growing season was delayed and the growing season length was first constant and then decreased with increasing elevation. In the case of the date of growing season maximum and end, our results along the elevation transects are similar to what would be expected from a precipitation gradient, and should be considered with more caution.

\section{Primary production forecasting}

Our results provide a basis to develop forage forecasting tools in the Patagonian steppe. In all of the studied areas, there was a lag between the start of the growing season and the winter precipitation period. Low winter temperatures control this lag and determine a period of low forage availability during fall and winter. The effects of temperature through time were clear and predictable, suggesting that we may forecast the starting date of the growing season during spring based on July mean temperature. Forecasting the growing season start will help to predict forage availability during lambing, which is a critical period with high forage demand. Yet, our results suggest that forecasting total annual production in the Patagonian steppe requires both longer data sets and experimental work going beyond the correlative models.

\section{Primary production and climate change}

The combination of regional gradients and temporal series in our work provided a better perspective on the potential effects of climate change on primary production than did purely spatial regional approaches. The differences between spatial and temporal responses of ANPP are crucial for improving our predictions of climate change effects upon ecosystem functioning. In our case, the temporal model for temperature effects on ANPP reflects the instantaneous response of vegetation to temperature. In contrast, the spatial model shows long-term effects of temperature that include changes of species composition and their corresponding temperature thresholds. If we use the spatial model to predict climate change effects, our results will underestimate changes; however, using the temporal model, our predictions will overestimate the effect. The real change will be somewhere in between both models and will be determined by the speed of temperature changes and the speed of adjustment of thresholds by species replacement and adaptations. 


\section{ACKNOWLEDGMENTS}

I. C. Burke, H. E. Epstein, W. K. Lauenroth, J. L. Mercau, M. Nogués Loza, M. Oesterheld, and S. W. Running provided valuable suggestions at different stages of this work. We wish to thank the Distributed Active Archive Center, Greenbelt, Maryland 20771, for producing the NDVI data in their present form and distributing them. The original data products were developed under the NOAA/NASA Pathfinder program, by a processing team headed by Mary James of the Goddard Global Change Data Center; and the science algorithms were established by the AVHRR Land Science Working Group, chaired by John Townshend of the University of Maryland. Goddard's contributions to these activities were sponsored by NASA's Mission to Planet Earth Program. This work was funded by the InterAmerican Institute for Global Change Research, U.S. National Science Foundation Cross Site LTER Project; University of Buenos Aires; FONCyT; and CONICET.

\section{Literature Cited}

Baker, F. S. 1944. Mountain climates of the Western United States. Ecological Monographs 14:225-254.

Barry, R. G. 1981. Mountain weather and climate. Methuen, London, UK.

Box, E. O., B. N. Holben, and V. Kalb. 1989. Accuracy of the AVHRR vegetation index as a predictor of biomass, primary productivity and net $\mathrm{CO}_{2}$ flux. Vegetatio 80:7189.

Briggs, J. M., and A. K. Knapp. 1995. Interannual variability in primary production in tallgrass prairie: climate, soil moisture, topographic position, and fire as determinants of aboveground biomass. American Journal of Botany 82: 1024-1030.

Burke, I. C. 2000. Landscape and regional biogeochemistry: approaches. Pages 277-288 in O. E. Sala, R. B. Jackson, H. A. Mooney, and R. W. Howarth, editors. Methods in ecosystem science. Springer-Verlag, New York, New York, USA.

Burke, I. C., W. K. Lauenroth, and C. A. Wessman. 1998. Progress in understanding biogeochemical cycles at regional to global scales. Pages 165-194 in P. Groffman and M. Pace, editors. Successes, limitations, and frontiers in ecosystem science. Springer-Verlag, New York, New York, USA.

Burke, I. C., C. M. Yonker, W. J. Parton, C. V. Cole, K. Flach, and D. S. Schimel. 1989. Texture, climate, and cultivation effects on soil organic matter content in U.S. grassland soils. Soil Science Society of America Journal 53:800-805.

Chapin, F. S. 1993. Functional role of growth forms in ecosystem and global processes. Pages 287-312 in J. R. Ehleringer and C. B. Field, editors. Scaling physiological processes: leaf to globe. Academic Press, London, UK.

Deffosé, G. E., M. B. Bertiller, and J. O. Ares. 1990. Aboveground phytomass dynamics in a grassland steppe of $\mathrm{Pa}-$ tagonia. Journal of Range Management 43:157-160.

Ehleringer, J. R. 1995. Variation in gas exchange characteristics among desert plants. Pages 361-408 in E.-D. Schulze and M. M. Caldwell, editors. Ecophysiology of photosynthesis. Springer-Verlag, Berlin, Germany.

Epstein, H. E., W. K. Lauenroth, and I. C. Burke. 1997. Effects of temperature and soil texture on ANPP in the U.S. Great Plains. Ecology 78:2628-2631.

Fernández, R. J., O. E. Sala, and R. A. Golluscio. 1991. Woody and herbaceous aboveground production of a $\mathrm{Pa}$ tagonian steppe. Journal of Range Management 44:434437.

Frank, D. A., and R. S. Inouye. 1994. Temporal variation in actual evapotranspiration of terrestrial ecosystems: patterns and ecological implications. Journal of Biogeography 21: 401-411.
Gallo, K. P., C. S. T. Daughtry, and M. E. Bauer. 1985. Spectral estimation of absorbed photosynthetically active radiation in corn canopies. Remote Sensing of the Environment 17:221-232.

Gamon, J. A., C. B. Field, M. L. Goulden, K. L. Griffin, A. E. Hartley, G. Joel, J. Peñuelas, and R. Valentini. 1995. Relationships between NDVI, canopy structure, and photosynthesis in three Californian vegetation types. Ecological Applications 4:322-343.

Golluscio, R. A., R. J. C. León, and S. B. Perelman. 1982. Caracterización fitosociológica de la estepa del oeste del Chubut. Su relación con el gradiente ambiental. Boletín de la Sociedad Argentina de Botánica 21:299-324.

Goward, S. N., R. H. Waring, D. G. Dye, and J. Yang. 1994. Ecological remote sensing at OTTER: satellite macroscale observations. Ecological Applications 4:322-343.

Graetz, R. D. 1991. Desertification: a tale of two feedbacks. Pages 59-87 in H. A. Mooney E. Medina, D. Schindler, E. D. Schulze, and B. H. Walker, editors. Ecosystem experiments. John Wiley, Chichíester, UK.

Hodgkinson, K. C. 1992. Elements of grazing strategies for perennial grass management in rangelands. Pages 77-94 in K. C. Hodgkinson, editor. Desertified grasslands: their biology and management. Linnean Society, London, UK.

Holben, B. 1986. Characteristics of maximum value composite images from temporal AVHRR data. International Journal of Remote Sensing 7:1417-1434.

James, M. E., and S. N. V. Kallury. 1994. The Pathfinder AVHRR land dataset: an improved coarse resolution dataset for terrestrial monitoring. International Journal of Remote Sensing 15:3347-3363.

Jenny, H. 1941. Factors of soil formation. McGraw-Hill, New York, New York, USA.

Jobbágy, E. G., J. M. Paruelo, and R. J. C. León. 1995. Estimación del régimen de precipitación a partir de la distancia a la cordillera en el noroeste de la Patagonia. Ecología Austral 5:47-53.

Jobbágy, E. G., J. M. Paruelo, and R. J. C. León. 1996. Vegetation heterogeneity and diversity in flat and mountain landscapes of Patagonia (Argentina). Journal of Vegetation Science 7:599-608.

Kennedy, P. 1989. Monitoring the vegetation of Tunisian grazing lands using the normalized differences vegetation index. Ambio 18:119-123.

Lauenroth, W. K. 1979. Grassland primary production: North American grasslands in perspective. Pages 3-24 in N. R. French, editor. Perspectives in grassland ecology. Ecological studies. Volume 32. Springer-Verlag, New York, New York, USA.

Lauenroth, W. K., H. W. Hunt, D. M. Swift, and J. S. Singh. 1986. Estimating aboveground net primary production in grasslands: a simulation approach. Ecological Modeling 33:297-314.

Lauenroth, W. K., and O. E. Sala. 1992. Long-term forage production of North American shortgrass steppe. Ecological Applications 2:397-403.

Law, B. E., and R. H. Waring. 1994. Remote sensing of leaf area index and radiation intercepted by understory vegetation. Ecological Applications 4:272-279.

Le Houérou, H. N. 1984. Rain-use efficiency: a unifying concept in arid land ecology. Journal of Arid Environments 7:1-35.

Le Houérou, H. N., R. L. Bingham, and W. Skerbek. 1988. Relationship between the variability of primary production and the variability of annual precipitation in world arid lands. Journal of Arid Environments 15:1-18.

León, R. J. C., and J. M. Facelli. 1981. Descripción de una coenoclina en el SO del Chubut. Revista Facultad de Agronomía 2:163-171.

McNaughton, S. J., O. E. Sala, and M. Oesterheld. 1993. 
Comparative ecology of African and South American arid to subhumid ecosystems. Pages 548-567 in P. Goldblatt, editor. Biological relationships between Africa and South America. Yale University Press, New Haven, Connecticut, USA.

Menteemeyer, V. 1978. Macroclimate and lignin control of litter decomposition rates. Ecology 59:465-472.

Monteith, J. L. 1981. Climatic variation and the growth of crops. Quarterly Journal of the Royal Meteorological Society 107:749-774.

Noy Meir, I. 1973. Desert ecosystems: environment and producers. Annual Review of Ecology and Systematics 4:2541.

Paruelo, J. M., M. R. Aguiar, R. J. C. León, R. A. Golluscio, and W. B. Batista. 1991. The use of satellite imagery in quantitative phytogeography: a case study of Patagonia (Argentina). Pages 183-204 in P. L. Nimis and T. J. Crovello, editors. Quantitative approaches to phytogeography. Kluwer Acedemic, The Hague, The Netherlands.

Paruelo, J. M., M. R. Aguiar, R. J. C. León, R. A. Golluscio, and G. Pujol. 1993. Environmental controls of NDVI dynamics in Patagonia based on NOAA-AVHRR satellite data. Journal of Vegetation Science 4:425-428.

Paruelo, J. M., H. E. Epstein, W. K. Lauenroth, and I. C. Burke. 1997. ANPP estimates from NDVI for the Central Grassland Region of the United States. Ecology 78:953958.

Prince, S. D. 1991. Satellite remote sensing of primary production: comparison of results for Sahelian grasslands 1981-1988. International Journal of Remote Sensing 12: 1301-1311.

Rao, C. R. N. 1993. Degradation of the visible and near infrared channels of the Advanced Very High Resolution Radiometer on the NOAA-9 spacecraft: assessment and recommendations for corrections. NOAA Technical Report NESDIS-70, NOAA/NESDIS, Washington, D.C., USA.

Ruimy, A., B. Saugier, and G. Dedieu. 1994. Methodology for the estimation of terrestrial net primary production from remotely sensed data. Journal of Geophysical Research 99: 5263-5283.

Running, S. W. 1990. Estimating terrestrial primary productivity by combining remote sensing and ecosystem simulation. Pages 65-86 in R. J. Hobbs and H. A. Mooney, editors. Remote sensing of biosphere functioning. SpringerVerlag, New York, New York, USA.

Sala, O. E., W. J. Parton, L. A. Joyce, and W. K. Lauenroth.
1988. Primary production of the central grassland region of the United States. Ecology 69:40-45.

Singh, J. S., W. K. Lauenroth, and R. K. Steinhorst. 1975. Review and assessment of various techniques for estimating net aerial primary production in grassland from harvest data. Botanical Review 41:181-232.

Smoliak, S. 1986. Influence of climatic conditions on production of Stipa-Bouteloua over 50-year period. Journal of Range Management 39:100-103.

Soriano, A. 1956. Los distritos florísticos de la provincia Patagónica. Revista de Investigaciones Agropecuarias 10: 323-347.

Soriano, A. 1983. Deserts and semi-deserts of Patagonia. Pages 432-460 in N. E. West, editor. Temperate deserts and semideserts. Elsevier, Amsterdam, The Netherlands.

Squeo, F. A., F. Rada, C. García, M. Ponce, A. Rojas, and A. Azócar. 1996. Cold resistance mechanisms in high desert Andean plants. Oecologia 105:552-555.

Tucker, C. J. 1980. Critical review of remote sensing and other methods for non-destructive estimation of standing crop biomass. Grass and Forage Science 35:177-182.

Tucker, C. J., and P. J. Sellers. 1986. Satellite remote sensing for primary production. International Journal of Remote Sensing 7:1395-1416.

Vitousek, P. M., G. Aplet, D. R. Turner, and J. J. Lockwood. 1992. The Mauna Loa environmental matrix: foliar and soil nutrients. Oecologia 89:372-382.

Vitousek, P. M., D. R. Turner, W. J. Parton, and R. L. Sanford. 1994. Litter decomposition on the Mauna Loa environmental matrix, Hawai'i: patterns, mechanisms, and models. Ecology 75:418-429.

Walter, H., and E. O. Box. 1983. Climate of Patagonia. Pages 432-435 in N. E. West, editor. Temperate deserts and semideserts. Elsevier, Amsterdam, The Netherlands.

Webb, W. L., S. Szarek, W. K. Lauenroth, R. Kinerson, and M. Smith. 1978. Primary production and water use on native forest, grassland, and desert ecosystems. Ecology 59: 1239-1247.

Wessman, C. A. 1992. Spatial scales and global change: bridging the gap for plots to GCM grid cells. Annual Review of Ecology and Systematics 23:175-200.

Woodward, F. I. 1987. Climate and plant distribution. Cambridge University Press. Cambridge, UK.

Woodward, F. I., and Ch. Körner. 1987. The dynamics of leaf extension in plants with diverse altitudinal ranges. II. Field studies in Poa species between 600 and $3200 \mathrm{~m}$ altitude. Oecologia 72:279-283. 